\title{
OPEN In-vitro propagation and phytochemical profiling of a highly medicinal and endemic plant species of the Himalayan region (Saussurea costus)
}

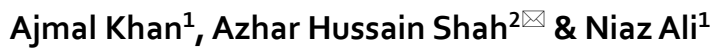

Efficient protocols for callus induction and micro propagation of Saussurea costus (Falc.) Lipsch were developed and phytochemical diversity of wild and in-vitro propagated material was investigated. Brown and red compact callus was formed with frequency of $80-95 \%, 78-90 \%, 70-95 \%$ and $65-80 \%$ from seeds, leaf, petiole and root explants, respectively. MS media supplemented with BAP (2.0 $\left.\mathrm{mgL}^{-1}\right)$, NAA $\left(1.0 \mathrm{mgL}^{-1}\right)$ and GA3 $\left(0.25 \mathrm{mgL}^{-1}\right)$ best suited for multiple shoot buds initiation (82\%), while maximum shoot length was formed on media with BAP $\left(1.5 \mathrm{mgL}^{-1}\right), \mathrm{NAA}\left(0.25 \mathrm{mgL}^{-1}\right)$ and Kinetin $\left(0.5 \mathrm{mgL}^{-1}\right)$. Full strength media with IAA $\left(0.5 \mathrm{mgL}^{-1}\right)$ along with IBA $\left(0.5 \mathrm{mgL}^{-1}\right)$ resulted in early roots initiation. Similarly, maximum rooting (87.57\%) and lateral roots formation (up to 6.76) was recorded on full strength media supplemented with BAP $\left(0.5 \mathrm{mgL}^{-1}\right)$, IAA $\left(0.5 \mathrm{mgL}^{-1}\right)$ and IBA $\left(0.5 \mathrm{mgL}^{-1}\right)$. Survival rate of acclimatized plantlets in autoclaved garden soil, farmyard soil, and sand (2:1:1) was $87 \%$. Phytochemical analysis revealed variations in biochemical contents i.e. maximum sugar $(808.32 \mu \mathrm{M} / \mathrm{ml})$, proline $(48.14 \mathrm{mg} / \mathrm{g})$, ascorbic acid $(373.801 \mathrm{mM} / \mathrm{g})$ and phenolic compounds $\left(642.72 \mathrm{mgL}^{-1}\right.$ ) were recorded from callus cultured on different stress media. Nonetheless, highest flavenoids $(59.892 \mathrm{mg} / \mathrm{g}$ ) and anthocyanin contents $(32.39 \mathrm{mg} / \mathrm{kg})$ were observed in in-vitro propagated plants. GC-MS analysis of the callus ethyl acetate extracts revealed 24 different phytochemicals. The variability in secondary metabolites of both wild and propagated plants/callus is reported for the first time for this species. This study may provide a baseline for the conservation and sustainable utilization of $S$. costus with implications for isolation of unique and pharmacologically active compounds from callus or regenerated plantlets.

Plants have been essential sources of medicine for thousands of years and nearly $80 \%$ of the world's population still relies on traditional medicine for their primary healthcare ${ }^{1}$. Saussurea costus is an endemic species in geographically limited places of the Himalayas, where it grows on moist slopes at altitudes of $2500-4000 \mathrm{~m}$. The species is critically endangered and is listed in Appendix I of the Convention on International Trade in Endangered Species of Wild Fauna and Flora (CITES). In addition, it is one of the 37 endangered and highly medicinal plants of the Himalayas, and has been prioritized for both in-situ and ex-situ conservation ${ }^{2}$. S. costus is a highly prized medicinal plant in the Kaghan valley Pakistan. Roots of $S$. costus have sweet and strong aromatic odor with bitter taste and are used as antiseptics as well as for treating bronchial asthma, especially of the vagotonic type. The roots of $S$. costus have been widely used for curing diarrhea, jaundice, stomachache, respiratory tract infections, antispasmodic agents against spasms caused by asthma, cholera, rheumatism, chronic skin diseases and leprosy ${ }^{3}$. Further, oil extracted from the roots (referred to as Costus oil) is used for making high grade perfumes and hair oils ${ }^{4}$. In addition, many studies have shown that extracts of $S$. costus have potent anti-cancer, anti-inflammatory and anti-ulcer properties ${ }^{5}$. Because of the high demands for roots, most natural populations of $S$. costus are on the verge of extinction ${ }^{6}$.

In order to avoid the future loss of endangered, endemic and rare species, conservation of plant genetic resources has long been realized as an integral part of biodiversity conservation. Plant cell and tissue culture 


\begin{tabular}{|l|l|l|l|}
\hline Samples & Kinetin $\left(\mathbf{m g L}^{-1}\right)$ & $\mathbf{2 , 4}-\mathbf{D}\left(\mathbf{m g L}^{-1}\right)$ & Callus stress \\
\hline CPM & 0.5 & 1.0 & -- \\
\hline CPM-1 & 0.5 & 1.0 & D-Sorbitol $\left(60 \mathrm{gL}^{-1}\right)$ \\
\hline CPM-2 & 0.5 & 1.0 & D-Manitol $\left(60 \mathrm{gL}^{-1}\right)$ \\
\hline CPM-3 & 0.5 & 1.0 & Poly ethylene glycol $600\left(5 \mathrm{gL}^{-1}\right)$ \\
\hline CPM-4 & 0.5 & 1.0 & Sucrose $\left(60 \mathrm{gL}^{-1}\right)$ \\
\hline
\end{tabular}

Table 1. Different stress for phytochemical comparison of callus grown on simple callus promoting media (CPM) supplemented with Kinetin $\left(0.5 \mathrm{mgL}^{-1}\right)$ and $2.4-\mathrm{D}\left(1.0 \mathrm{mgL}^{-1}\right)$ and callus subjected to various stresses i.e. $60 \mathrm{gL}^{-1}$ D-Sorbitol stress (CPM-1), $60 \mathrm{gL}^{-1} \mathrm{D}$-Manitol (CPM-2), $5 \mathrm{gL}^{-1}$ Poly ethylene glycol 600 (CPM-3) and $60 \mathrm{gL}^{-1}$ Sucrose (CPM-4).

has been a powerful tool for rapid propagation and biomass production of valuable species. To overcome environmental constraints in-vitro cultures (cell, callus, buds and shoot) provide the best alternative choice for the smooth and constant supply of plant active ingredients ${ }^{7}$. However, there are no effort in literature for $e x$-situ conservation and micro propagation of $S$. costus. Further, phytochemical composition of the wild (natural) $S$. costus and tissue culture generated material is totally non-existent. The purpose of this research was to establish an effective and efficient in vitro regeneration protocol for $S$. costus and to compare the photochemical variability in the aqueous extracts of induced callus, in-vitro propagated plants with the wild/natural collections.

\section{Materials and Methods}

Plant material and sterilization procedure. Mother plant was collected from wild populations in Makra, Kaghan valley, Pakistan (lat $34.57439^{\circ} \mathrm{N}$, long $073.49580^{\circ} \mathrm{E}$, alt 3,878 $\mathrm{m}$ ). The specimen was identified by Dr. Abdul Majid Department of Botany Hazara University Mansehra, and scientific name validated online (http://www.theplantlist.org/). Voucher specimen was submitted to the Herbarium Department of Botany Hazara University, Mansehra. Healthy plant parts (explant) were separated from the mother plant, washed and sterilized following Yesmin et al. $(2016)^{8}$.

Culture conditions. The basal MS media ${ }^{9}$ was used with various concentration and composition of growth regulators (BAP, IAA, IBA, NAA, 2,4-D and kinetin). All culture media were agitated with 7\% technical agar and $3 \%$ sucrose. The $\mathrm{pH}$ of media was set to 5.8 before addition of agar. These media were autoclaved at $121^{\circ} \mathrm{C}$ for $20 \mathrm{~min}$ at $15 \mathrm{psi}$. Cultures were maintained in a culture room incubated with a 16-h light cycle and temperature maintained at $25 \pm 2{ }^{\circ} \mathrm{C}$ with $50 \%$ humidity.

Callus induction. Growth regulators such as 2,4-D $\left(0.25,0.5\right.$, and $\left.1.0 \mathrm{mgL}^{-1}\right)$ in combination with varied concentration of Kinetin $\left(0.5,1.0,1.5\right.$ and $\left.2.0 \mathrm{mgL}^{-1}\right)$, and four explants types (seeds, leaf, petiole and internode) were compared for callus induction. Explants were subjected to two subcultures at an interval of fourteen days ${ }^{10}$.

Shoot bud initiation. Full strength MS media with different concentration of BAP $\left(0.5,1.0,2.0 \mathrm{mgL}^{-1}\right)$, NAA $\left(0,0.25,1.0 \mathrm{mgL}^{-1}\right)$ and $\mathrm{GA}_{3}\left(0,0.25,1.0 \mathrm{mgL}^{-1}\right)$ were compared for shoot buds initiation. The percentage of shoot induction, time taken for bud initiation and the growth state of the buds were measured after four weeks of culturing.

Shoot proliferation. Nodal segments (1-2 cm long) were excised from cultured plant and transferred into MS media agitated with BAP $\left(0.5,1.0,1.5 \mathrm{mgL}^{-1}\right)$ in combination with NAA $\left(0.25,0.25\right.$ and $\left.0.5 \mathrm{mgL}^{-1}\right)$ and Kinetin $\left(0,0.25\right.$ and $\left.0.5 \mathrm{mgL}^{-1}\right)$ in order to maximize shoot multiplication. In addition, basic MS media with different plant growth regulators were compared during the phase of subculture, and the optimal media for shoot proliferation was selected.

Root initiation. To optimize root induction media, full-strength MS media was supplemented with different combination and concentrations of IAA $\left(0.5,1.0 \mathrm{mgL}^{-1}\right)$ and IBA $\left(0.5,0.1 \mathrm{mgL}^{-1}\right)$ along BAP $\left(0.5 \mathrm{mgL}^{-1}\right)$. The time to root initiation was observed and recorded after every two days. Data on average root numbers and length were recorded after 45 days of culturing.

Photochemical analysis. Treatments of in-vitro callus. After subculture for eight cycles, fourteen days old callus was subjected to four different stresses each having five (05) replications. Callus was cultured on callus promoting media (CPM) having 0.5 and $1.0 \mathrm{mgL}^{-1}$ Kinetin and 2.4-D respectively. In addition, callus was cultured on media agitated with $60 \mathrm{gL}^{-1} \mathrm{D}$-Sorbitol stress (CPM-1), $60 \mathrm{gL}^{-1} \mathrm{D}$-Manitol stress (CPM-2), $5 \mathrm{gL}^{-1} \mathrm{Poly}$ ethylene glycol 600 stress (CPM-3) and $60 \mathrm{gL}^{-1}$ Sucrose stress (CPM-4) for 120 days, while the callus cultured on CPM alone was considered as control (Table 1). Similarly, different concentrations of growth hormones given to calli for bud, shoot or root induction are given (see Tables 2-5).

Samples preparation. Samples for spectrometry (BMS, UV-1900) were prepared following Storey and Jones $(1975)^{11}$. Total sugars contents were analyzed following Dubois et al. $(1956)^{12}$, proline content was assessed fol- 


\begin{tabular}{|c|c|c|c|c|}
\hline Treatments & Conc. 2,4-D/Kinetin $\mathrm{mgL}^{-1}$ & Type of explants used & $\begin{array}{l}\text { Means days to callus induction } \\
(x- \pm S E)\end{array}$ & $\begin{array}{l}\text { Callus growth after } 30 \text { days } \\
(x- \pm \text { SE) }\end{array}$ \\
\hline \multirow{4}{*}{$\mathrm{T} 1$} & \multirow{4}{*}{$0.25 / 0.5$} & Seeds & $14.00 \pm 1.09^{\mathrm{A}}$ & $0.22 \pm 0.07^{\mathrm{D}}$ \\
\hline & & Leaf & $15.20 \pm 0.73^{\mathrm{C}}$ & $1.50 \pm 0.08^{\mathrm{AB}}$ \\
\hline & & Petiole & $15.80 \pm 0.73^{4 \mathrm{BC}}$ & $0.91 \pm 0.02^{\mathrm{D}}$ \\
\hline & & Root & $16.40 \pm 0.97^{\mathrm{A}}$ & $0.91 \pm 0.05 \mathrm{~B}^{\mathrm{C}}$ \\
\hline \multirow{4}{*}{$\mathrm{T} 2$} & \multirow{4}{*}{$0.5 / 0.5$} & Seeds & $17.60 \pm 0.67^{\mathrm{A}}$ & $1.39 \pm 0.06^{\mathrm{CD}}$ \\
\hline & & Leaf & $17.20 \pm 0.37^{\mathrm{C}}$ & $1.34 \pm 0.04^{\mathrm{AB}}$ \\
\hline & & Petiole & $17.80 \pm 0.37^{\mathrm{AB}}$ & $1.27 \pm 0.08^{\mathrm{BC}}$ \\
\hline & & Root & $19.20 \pm 0.37^{\mathrm{AB}}$ & $0.92 \pm 0.02^{\mathrm{B}}$ \\
\hline \multirow{4}{*}{ T3 } & \multirow{4}{*}{$0.5 / 1.0$} & Seeds & $13.40 \pm 0.60^{\mathrm{A}}$ & $1.86 \pm 0.06^{\mathrm{A}}$ \\
\hline & & Leaf & $15.80 \pm 1.07^{\mathrm{C}}$ & $1.65 \pm 0.06^{\mathrm{A}}$ \\
\hline & & Petiole & $15.60 \pm 0.50^{\mathrm{C}}$ & $1.42 \pm 0.05^{\mathrm{A}}$ \\
\hline & & Root & $17.40 \pm 0.86^{\mathrm{BC}}$ & $1.114 \pm 0.07^{\mathrm{A}}$ \\
\hline \multirow{4}{*}{$\mathrm{T} 4$} & \multirow{4}{*}{$0.5 / 1.5$} & Seeds & $16.60 \pm 0.60^{A}$ & $1.62 \pm 0.05^{\mathrm{B}}$ \\
\hline & & Leaf & $18.60 \pm 1.07^{\mathrm{AB}}$ & $1.32 \pm 0.08^{\mathrm{AB}}$ \\
\hline & & Petiole & $18.60 \pm 0.50^{\mathrm{A}}$ & $1.33 \pm 0.02^{\mathrm{AB}}$ \\
\hline & & Root & $17.20 \pm 0.86^{\mathrm{BC}}$ & $0.75 \pm 0.08^{\mathrm{C}}$ \\
\hline \multirow{4}{*}{ T5 } & \multirow{4}{*}{$0.5 / 2.0$} & Seeds & $17.40 \pm 1.07^{\mathrm{A}}$ & $1.54 \pm 0.08^{\mathrm{BC}}$ \\
\hline & & Leaf & $18.20 \pm 0.66^{\mathrm{AB}}$ & $1.23 \pm 0.06^{\mathrm{BC}}$ \\
\hline & & Petiole & $18.40 \pm 0.50^{\mathrm{A}}$ & $1.26 \pm 0.03^{\mathrm{BC}}$ \\
\hline & & Root & $19.40 \pm 0.74^{\mathrm{AB}}$ & $0.90 \pm 0.01^{\mathrm{BC}}$ \\
\hline \multirow{4}{*}{ T6 } & \multirow{4}{*}{$1.0 / 2.0$} & Seeds & $18.20 \pm 0.80^{\mathrm{A}}$ & $1.65 \pm 0.06^{\mathrm{B}}$ \\
\hline & & Leaf & $19.60 \pm 0.81^{\mathrm{A}}$ & $0.92 \pm 0.20^{\mathrm{C}}$ \\
\hline & & Petiole & $19.01 \pm 0.89^{\mathrm{A}}$ & $1.18 \pm 0.06^{\mathrm{C}}$ \\
\hline & & Root & $20.80 \pm 0.73^{\mathrm{A}}$ & $0.84 \pm 0.03^{\mathrm{BC}}$ \\
\hline
\end{tabular}

Table 2. In-vitro callus induction and callus growth after 30 days of culturing of $S$. costus using seed, leaf, petiole and root as an explants.

lowing Bates et al. $(1973)^{13}$, flavenoids were assessed as per Csepregi et al. (2013) ${ }^{14}$. Antioxidant activity was as described in Re et al. (1999) ${ }^{15}$, total phenol contents was measured following Singleton and Rossi (1965) ${ }^{16}$ and total anthocyanin content was determined following Giusti and Wrolstad $(2001)^{17}$.

Preparation of solvent extraction for GC-MS. Callus subjected to different stresses (Table 1) as well as grown on CPM was shade dried and grounded to fine powder using mortar and pestle. For solvent preparation $1 \mathrm{~g}$ (dry weight) of powder was soaked in $10 \mathrm{ml}$ of ethyl acetate for 2 days. The sample was centrifuged at $8,000 \mathrm{rpm}$ for 5 min and the supernatant collected was stored at $4{ }^{\circ} \mathrm{C}$ for further analyses ${ }^{18}$.

Gas chromatography-mass spectrometry (GC-MS) analysis. Chemical analysis of ethyl acetate extract was carried out using gas chromatography coupled with mass spectrometry (GC-MS) with a Hewlett Packard GCMS system (PerkinElmer precisely, Carlus 600C). The relative percentage of each component was calculated by comparing the average GC chromatogram peak to the total area. The mass detector used in this analysis was Turbo-Mass Gold-Perkin-Elmer, and the software adopted to handle mass spectra and chromatograms was a Turbo-Mass ver-5.4 ${ }^{19}$.

Identification of compounds. Interpretation on mass spectrum GC-MS was conducted using the database of National Institute Standard and Technology (NIST). The spectrum of a component was compared with the spectrum of the known components stored in the NIST library. Similarly, name, molecular weight and structure of the components of the test materials were ascertained ${ }^{19}$.

Statistical analysis. Statistical analysis was performed with Statistic 8.1 (Trial version). Results were presented as mean \pm standard error (SE), and the data was analyzed by one way Analysis of variance (ANOVA) at $0.05 \%$ confidence level $(\mathrm{p}<0.01)$. All in-vitro propagation treatments had 5 replications whereas; the phytochemical analyses had three replications for each treatment.

\section{Results and discussion}

Callus induction. Callus response was influenced by hormonal combinations as well as the type of explant used. The callus response varied i.e. $80-95 \%, 78-90 \%, 70-95 \%$ and $65-80 \%$ for seeds, leaf, petiole and root explants, respectively (Fig. 1A-H). Similarly, explants were grown on MS media alone (as control) for 14 days and no callus induction or regeneration was observed and therefore, these results are not included. Maximum 


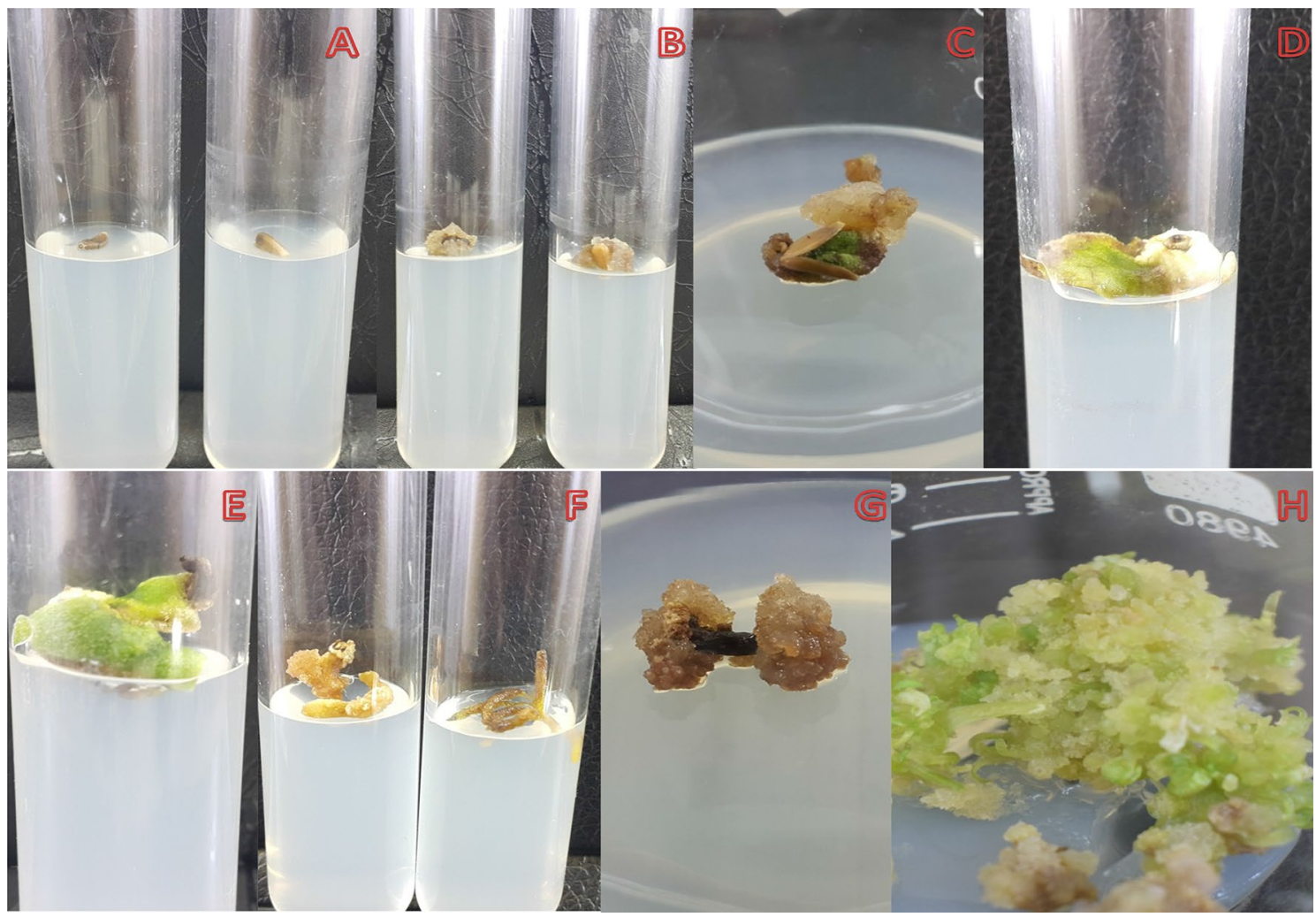

Figure 1. In-vitro callus induction of $S$. costus using seeds $(\mathbf{A}, \mathbf{B}, \mathbf{C})$, leaf $(\mathbf{D}, \mathbf{E})$, roots $(\mathbf{F})$ and nodes $(\mathbf{G})$ as an explant.

amount of callus tissue per seed explant was formed on MS media agitated with 2,4-D $\left(0.5 \mathrm{mgL}^{-1}\right)$ and Kinetin $\left(1.0 \mathrm{mgL}^{-1}\right)$ as demonstrated in Fig. 1A-C. The colour of callus ranged from white to dark brown. Successful callus initiation was observed after 13,15, 15 and 16 day of culturing from seed, leaf, petiole and root explants respectively (Table 2). It was also noted that subculture of callus into new media increased the callus biomass. Maximum callus growth from seed $(1.86 \mathrm{~g})$, leaf $(1.65 \mathrm{~g})$, petiole $(1.42 \mathrm{~g})$ and root $(1.14 \mathrm{~g})$ were record at 2, 4-D $\left(0.5 \mathrm{mgL}^{-1}\right)$ and Kinetin $\left(1.0 \mathrm{mgL}^{-1}\right)$ after twenty-eight days of culture (Table 2). Higher concentration of 2,4-D reduced callus induction and it was observed that the colour changed to brown with hard texture, followed by necrosis. Although 2,4-D is a synthetic plant growth regulator, its role in callus induction is highlighted for $S$. costus. Previous studies have also reported the efficacy of exogenous 2,4-D in other medicinal plants. Hassan et al. (2009) ${ }^{20}$ and Sen et al. (2014) $)^{21}$ have shown the positive role of 2,4-D plant growth hormones in culture media of W. somnifera, I. obscura, A. precatorius and C. halicacabum and their results are in agreement to those mentioned here. The effect of 2,4-D in combination with Kinetin demonstrated the potential of a synthetic plant growth regulators in the production of callus from seeds, leaf, petiole as well as root explants of $S$. costus as a potent plant growth regulator.

Shoot bud initiation. Auxiliary buds induction was observed after 15 to 20 days of culturing (Fig. 2A,B). The earliest shoot bud initiations were observed on media agitated with BAP $\left(2 \mathrm{mgL}^{-1}\right)$, NAA $\left(1 \mathrm{mgL}^{-1}\right)$ and GA3 $\left(0.25 \mathrm{mgL}^{-1}\right)$. Higher concentration of BAP resulted in earlier buds induction. The analysis revealed BAP had a marked influence on the rate of induction. Similarly, BAP in low concentration, the induction rate was $64 \%$ and the lateral buds sprouted late. In addition, new buds were relatively thinner and delicate. ANOVA showed that shoot bud initiation was highly significant among the treatments (Table 3). Previous studies have also indicated that high level of BAP and low $\mathrm{GA}_{3}$ induced greater response to shoot buds initiation ${ }^{22}$. Similarly, BAP here was most effective for bud induction. $\mathrm{GA}_{3}$ contributes to the initiation and elongation of auxiliary buds and expansion of leaves ${ }^{23}$. Further, $\mathrm{GA}_{3}$ regulates the growth and development of plants, mainly by stimulating mitotic division and cell elongation ${ }^{24}$. It was found that high level of $\mathrm{GA}_{3}$ effectively increased stem length, while lower $\mathrm{GA}_{3}$ concentration inhibited potato shoot growth ${ }^{25}$. Further, $\mathrm{GA}_{3}$ has long been used to break dormancy and to stimulate shoot elongation in different species of magnolias ${ }^{26}$. In line with the previous reports, it was also observed that BAP in combination with $\mathrm{GA}_{3}$ was important for bud initiation, reducing time for buds initiation as well as resulted in stronger buds ${ }^{27}$.

Shoot bud proliferation. Full strength media augmented with BAP $\left(0.1 \mathrm{mgL}^{-1}\right)$, NAA $\left(0.25 \mathrm{mgL}^{-1}\right)$ and Kinetin $\left(0.25 \mathrm{mgL}^{-1}\right)$ proved best for shoot bud proliferation and elongation (Fig. 2C). Significant differences were observed in multiplication rate and numbers of shoots between T7, T8 and T9, although T13 is significantly 


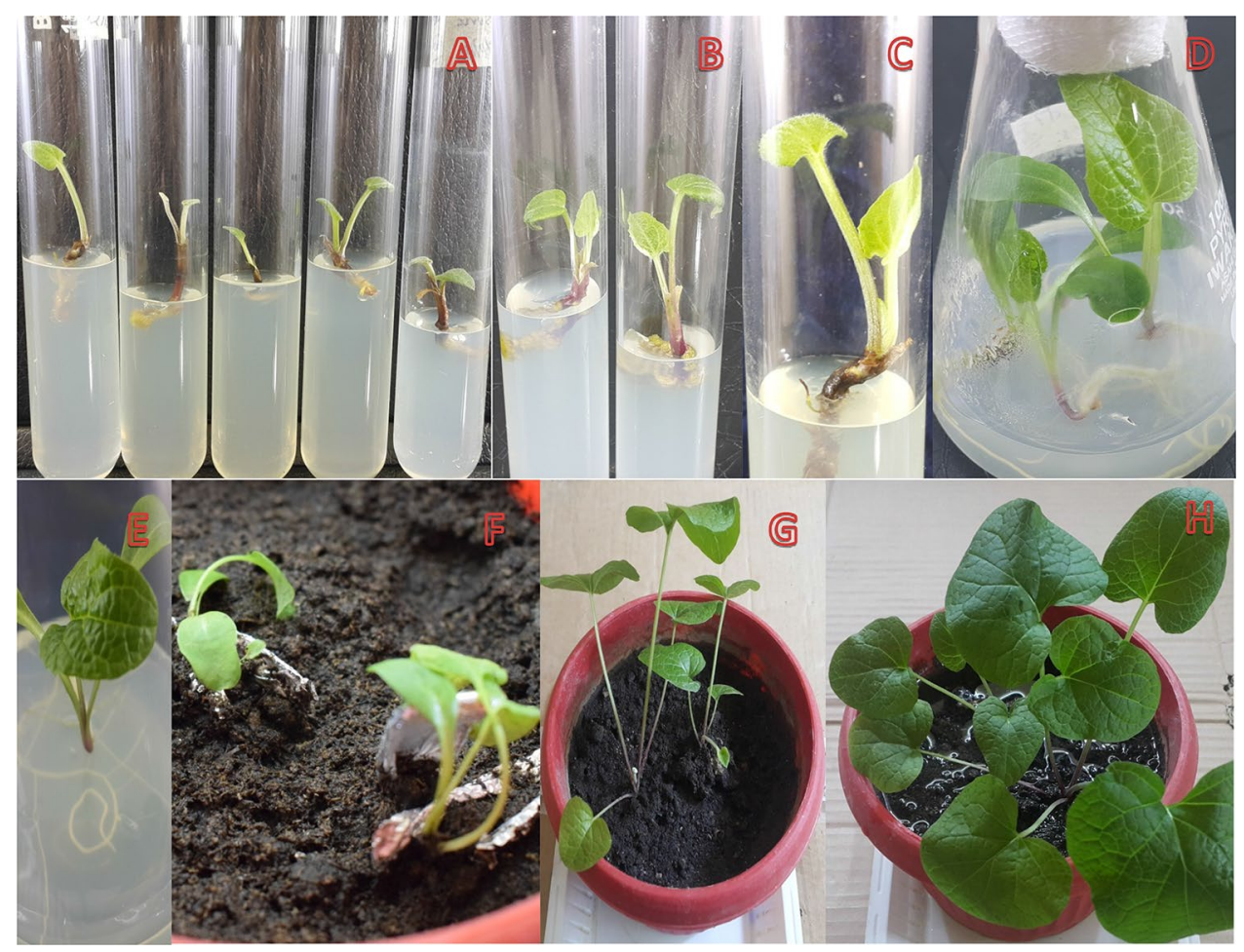

Figure 2. In-vitro Propagation of S. costus using nodal explant (A) Auxiliary buds, (B) Shoot buds initiation, (C) Multiple shoot initiation, (D, E, F) Mature plantlets, (E, F) Roots initiation, (G, H) Acclimatization of plants.

\begin{tabular}{|c|c|c|c|c|c|c|}
\hline Treatment & BAP $\mathrm{mgL}^{-1}$ ) & 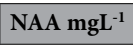 & $\mathrm{GA}_{3} \mathrm{mgL}^{-1}$ & Bud induction rate $(x- \pm S E)$ & Time to bud initiation & Growth state of bud \\
\hline $\mathrm{T} 7$ & 0.5 & 0 & 0 & $19.40 \pm 1.50^{\mathrm{A}}$ & 19 Days & + \\
\hline $\mathrm{T} 8$ & 0.5 & 0.25 & 0 & $17.80 \pm 1.02^{\mathrm{AB}}$ & 18 Days & ++ \\
\hline T9 & 1.0 & 0 & 0.25 & $17.60 \pm 0.37^{\mathrm{AB}}$ & 18 Days & +++ \\
\hline T10 & 1.0 & 0.25 & 0.25 & $17.00 \pm 0.44^{\mathrm{AB}}$ & 17 Days & +++ \\
\hline T11 & 2.0 & 1.0 & 0.25 & $15.60 \pm 0.87^{\mathrm{B}}$ & 15 Days & +++ \\
\hline T12 & 2.0 & 1.0 & 1.0 & $16.40 \pm 0.67^{\mathrm{B}}$ & 16 Days & +++ \\
\hline
\end{tabular}

Table 3. Influence of different plant growth regulators on buds initiation and Range analysis. Vigorous and green buds $(+++)$; healthy buds $(++)$; weak bud $(+)$. Each Value represents the mean $\pm S E$ of five replicates. Significant deference at $\mathrm{P} \leq 0.05, \mathrm{x}^{-} \pm \mathrm{Sd}$ - average \pm Standard deviation, $\mathrm{x} \pm \mathrm{SE}-$ average \pm Standard error.

\begin{tabular}{|l|l|l|l|l|l|l|}
\hline Treatments & $\mathbf{B A P}\left(\mathbf{m g L}^{-1}\right)$ & $\mathbf{N A A}\left(\mathbf{m g L}^{-\mathbf{1}}\right)$ & Kinetin $\left(\mathbf{m g L}^{-1}\right)$ & $\begin{array}{l}\text { shoots numbers per plant } \\
(\geqq \mathbf{0 . 5} \mathbf{~ c m})(\mathbf{m e a n} \pm \mathbf{S E})\end{array}$ & $\begin{array}{l}\text { shoots numbers per plant } \\
(\geqq \mathbf{0 . 5} \mathbf{c m})(\mathbf{m e a n} \pm \mathbf{S E})\end{array}$ & $\begin{array}{l}\text { Total shoot length }(\geqq \mathbf{0 . 5} \mathbf{~ c m}) \\
(\mathbf{m e a n} \pm \mathbf{S E})\end{array}$ \\
\hline T13 & 0.5 & 0.25 & 0 & $2.20 \pm 0.44$ & $2.20 \pm 0.20^{\mathrm{B}}$ & $2.19 \pm 0.26^{\mathrm{B}}$ \\
\hline T14 & 1.0 & 0.25 & 0.25 & $4.00 \pm 0.70$ & $4.00 \pm 0.31^{\mathrm{A}}$ & $2.50 \pm 0.30^{\mathrm{AB}}$ \\
\hline T15 & 1.5 & 0.25 & 0.5 & $2.80 \pm 0.83$ & $2.80 \pm 0.37^{\mathrm{B}}$ & $3.11 \pm 0.33^{\mathrm{A}}$ \\
\hline
\end{tabular}

Table 4. The influence of different concentrations of plant growth regulators on bud proliferation of $S$. costus. vigorous and green buds $(+++)$; healthy buds $(++)$; weak buds $(+)$. Each value represents the mean \pm SE of five replicates.

different from T14 and T15, while T13 and T14 are not significantly different (Table 4). Das et al. $(2020)^{28}$ has also recorded maximum number of shoot/explant of B. polystachyon with combination of BAP $(13.32 \mu \mathrm{M})$ and NAA $(0.53 \mu \mathrm{M})$. Several medicinal plants such as, C. paniculatus ${ }^{29}$ and C. blumei ${ }^{30}$, have shown similar results and BAP with NAA have been reported as being the most effective in direct organogenesis. Our results are in alignment to those of Kaur et al. (1998) ${ }^{31}$, where 8-10 shoot/explants of $A$. catechu from nodal segment on media containing BAP $\left(4.0 \mathrm{mgL}^{-1}\right)$ with NAA $\left(0.5 \mathrm{mgL}^{-1}\right)$ were reported. 


\begin{tabular}{|l|l|l|l|l|l|l|}
\hline Treatment & $\mathbf{B A P}\left(\mathbf{m g L}^{-1}\right)$ & $\mathbf{I A A}\left(\mathbf{m g L}^{-1}\right)$ & $\mathbf{I B A}\left(\mathbf{m g L}^{-\mathbf{1}}\right)$ & $\begin{array}{l}\text { Days to root initation } \\
(\mathbf{m e a n} \pm \mathbf{S E})\end{array}$ & $\begin{array}{l}\text { Number of roots } \\
(\mathbf{m e a n} \pm \mathbf{S E})\end{array}$ & $\begin{array}{l}\text { Total root length } \\
(\mathbf{c m})(\mathbf{m e a n} \pm \mathbf{S E})\end{array}$ \\
\hline T16 & 0.5 & 1.0 & 0 & $18.80 \pm 1.01^{\mathrm{A}}$ & $3.84 \pm 0.508^{\mathrm{B}}$ & $1.50 \pm 0.19^{\mathrm{B}}$ \\
\hline T17 & 0.5 & 0 & 1.0 & $16.20 \pm 0.80^{\mathrm{AB}}$ & $5.32 \pm 0.531^{\mathrm{AB}}$ & $2.53 \pm 0.21^{\mathrm{A}}$ \\
\hline T18 & 0.5 & 0.5 & 0.5 & $13.80 \pm 0.91^{\mathrm{B}}$ & $6.76 \pm 0.733^{\mathrm{A}}$ & $2.27 \pm 0.24^{\mathrm{A}}$ \\
\hline
\end{tabular}

Table 5. The effect of different concentrations of IAA and IBA along with BAP on roots initiation, number of roots and total root length of $S$. costus. Each value represents mean \pm SE of five replicates.

Total shoot length. Average shoot length ranged from 2.19 to $3.11 \mathrm{~cm}$ among the treatments. Maximum shoot length was recorded for media fortified with BAP $\left(1.5 \mathrm{mgL}^{-1}\right)$, NAA $\left(0.25 \mathrm{mgL}^{-1}\right)$ and Kinetin $\left(0.5 \mathrm{mgL}^{-1}\right)$. While, the minimum shoot length was recorded in media with BAP $\left(0.5 \mathrm{mgL}^{-1}\right)$, NAA $\left(0.25 \mathrm{mgL}^{-1}\right)$ without Kinetin (Fig. 2D,E). ANOVA revealed significant variation in T15 compared to T13 and T14 (Table 4). The addition of even smaller amounts of BAP or NAA help inducing adventitious shoot formation by increasing propagation coefficient ${ }^{32}$. Other researchers have also reported that highest shoot length $(3.73 \pm 0.14 \mathrm{~cm})$ of $S$. rebaudiana was observed on MS media supplemented with BAP $\left(2.0 \mathrm{mgL}^{-1}\right)$ and IAA $\left(0.25 \mathrm{mgL}^{-1}\right)$ after 15 days of culturing ${ }^{33}$. Additionally, higher concentrations of BAP reduces shoot length, which is in agreement to the known literature ${ }^{34}$.

Root initiation, number of roots and total root length. Roots induction is a critical step in successful in-vitro propagation experiments; here combination of IAA $\left(0.5 \mathrm{mgL}^{-1}\right)$ with IBA $\left(0.5 \mathrm{mgL}^{-1}\right)$ resulted in earliest roots initiation (13 days), while IAA $\left(0.1 \mathrm{mgL}^{-1}\right)$ delayed late root formation (19 days) (Fig. 2D-E). Further, IAA $\left(0.5 \mathrm{mgL}^{-1}\right)$ in combination with IBA $\left(0.5 \mathrm{mgL}^{-1}\right)$ resulted in earliest as well as plenty of lateral roots formation (Table. 5). ANOVA showed that TI6 was significantly different, while T17 and T18 had no significant variation (Table 5). IBA is a highly stable and potential auxin for roots induction ${ }^{35}$. Maximum numbers of roots (6.76) were recorded on full strength media supplemented with BAP $\left(0.5 \mathrm{mgL}^{-1}\right)$, IAA $\left(0.5 \mathrm{mgL}^{-1}\right)$ and IBA $\left(0.5 \mathrm{mgL}^{-1}\right)$ (Fig. 2E). On the contrary, least number of roots per plant (3.84) were formed on media supplemented with IAA $\left(1 \mathrm{mgL}^{-1}\right)$. Statistical analysis revealed that T16 and T18 varied significantly (Table 5 ). The in-vitro derived shoots on MS medium were supplemented with a range of concentrations of two auxins (IAA and IBA) for 75 days, it was observed that the lower concentrations of BAP $\left(0.5 \mathrm{mgL}^{-1}\right)$ in combination with IBA $\left(1 \mathrm{mgL}^{-1}\right)$ resulted in a higher root length $(2.53 \mathrm{~cm})$, while IAA $\left(1 \mathrm{mgL}^{-1}\right)$ and IBA $\left(1 \mathrm{mgL}^{-1}\right)$ alone induced roots length of $(1.5 \mathrm{~cm})$ and $(2.27 \mathrm{~cm})$ respectively. Results showed that IAA in comparison to IBA reduced roots length when compared at the same concentration (Table 4). Statistical analysis showed that root length at T16 was significantly different from T17 and T18. Cheepala et al. (2004) ${ }^{36}$ reported that IAA is a widely used auxin for rooting in A. stenosperma and A. villosa. In several other plants species the promoting effect of IBA in rooting has also been reported ${ }^{37}$. In contrast, induction of rooting of $G$. scabra was obtained on NAA $\left(0.3 \mathrm{mgL}^{-1}\right)$ and IAA $(0.1$ $\mathrm{mgL}^{-1}$ ) containing media ${ }^{38}$. Similarly higher percentage of rooting were obtained in half strength MS media with NAA $\left(1.0 \mathrm{mgL}^{-1}\right)$, were as full strength medium with NAA $\left(1.5 \mathrm{mgL}^{-1}\right)$ was the best media for rooting ${ }^{10}$. Bekheet $(2013)^{39}$ has indicated that addition of IAA, IBA or NAA $\left(1 \mathrm{mgL}^{-1}\right)$ induced rooting of in-vitro grown P. dactylifera. However, in the present study, IAA in combination with IBA was found to be the most efficient in multiple shoots induction, followed by IBA alone.

Acclimatization. The ultimate success of all in-vitro micro propagation endeavors heavily relies on the higher survival rates of such plantlets. Direct field transfers of the plantlets do not allow acclimatization of the in-vitro generated plants as they fail to establish successful interactions with the soil microbes and/or to sustain the environmental conditions ${ }^{40}$. Here, well rooted micro propagated plantlets were transferred into plastic pots containing autoclaved garden soil, farmyard soil, and sand (2:1:1) as shown in Fig. $2 \mathrm{~F}-\mathrm{H}$. The plants were then acclimatized in the growth room at $27^{\circ} \mathrm{C}$ temperature for 2 weeks followed by another 3 weeks at room temperature under laboratory conditions. Finally, 35-40 days old plantlets were transferred to nursery where, morphological anatomical and growth characteristics were observed (results not shown) and survival efficiency recorded. Out of 92 plantlets, $80(87 \%)$ could successfully acclimatize and the relatively low mortality rate here is likely to be due to the biohardening of the micropropagated plants achieved prior to their nursery transfer. Similarly, we have given water to the plantlets after 6 days interval and that too very close to the roots and have avoided leaves. This approach has been previously reported beneficial for in-vitro raised plants ${ }^{41}$ and the survival rate could be raised significantly higher if biotization of the explants is attempted ${ }^{42}$.

Phytochemical variation. Total sugar contents. Total sugar contents revealed significant variation with treatments. Maximum sugar contents $(808.326 \mu \mathrm{M} / \mathrm{ml})$ was observed in callus cultured on CPM-4 supplemented with $60 \mathrm{gL}^{-1}$ sucrose, while the lowest sugar contents $(16.64 \mu \mathrm{M} / \mathrm{ml})$ was noted in wild plants (Fig. 3A). Accumulation of sugars contents in different parts of plants increases in response to a variety of environmental stresses $^{43}$. The accumulation of total sugars is associated with adaptation of plants to various environmental stresses $^{44}$. The results shown here are in agreement to earlier findings where salinity increased total sugar contents in leaves of in-vitro propagated P. euphratica. Similarly, addition of $\mathrm{NaCl}\left(250 \mathrm{mmoll}^{-1}\right)$ increased sugars contents by 2.7 times $^{45}$. In calli of $M$. arborea total sugars account for about $90 \%$ of the total dry weight and there were no significant differences. The remarkable differences between the embryogenic and non-embryogenic calli of $M$. arborea, was the amount of sugar found in embryogenic calli ${ }^{46}$. A similar trend with total sugars ac- 

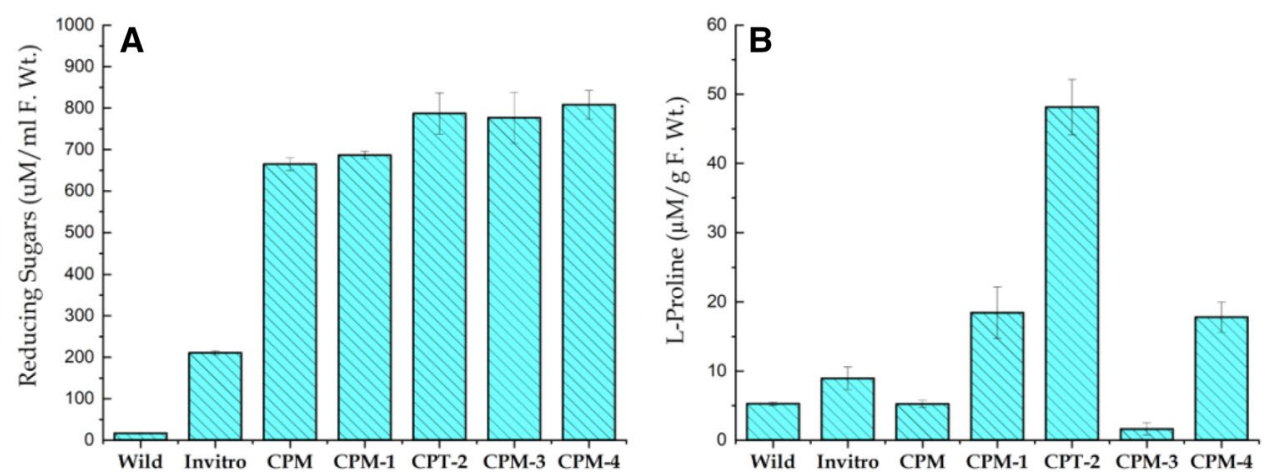

Figure 3. Variation in the Total Sugar contents (A) and proline contents (B) of S. costus collected from wild, in-vitro propagated plant and induced callus. Different stress for phytochemical comparison of callus grown on simple callus promoting media (CPM) supplemented with Kinetin $\left(0.5 \mathrm{mgL}^{-1}\right)$ and $2.4-\mathrm{D}\left(1.0 \mathrm{mgL}^{-1}\right)$ and callus subjected to various stresses i.e. $60 \mathrm{gL}^{-1} \mathrm{D}$-Sorbitol stress (CPM-1), $60 \mathrm{gL}^{-1} \mathrm{D}$-Manitol (CPM-2), $5 \mathrm{gL}^{-1}$ Poly ethylene glycol 600 (CPM-3) and $60 \mathrm{gL}^{-1}$ Sucrose (CPM-4).

cumulation was also detected in $P$. kurroa ${ }^{47}$. In line results are also shown for the total sugars in selected calli of D. caryophyllus subjected to different concentrations of culture filtrate that were significantly higher than those of non selected calli ${ }^{48}$.

Proline content. Since, callus promoting media was used as a control; the stresses imposed increased proline content in callus from 1.63 to $48.14 \mathrm{mg} / \mathrm{g}$ F.Wt. The variability in proline content among the different treatments were highly significant as shown in Fig. 3B. Maximum proline contents was noticed in CPM-2 agitated with $60 \mathrm{gL}^{-1} \mathrm{D}$-Manitol $(48.14 \mathrm{mg} / \mathrm{g})$ whereas, minimum was observes in CPM-3 supplemented with $5 \mathrm{gL}^{-1} \mathrm{Poly}$ ethylene glycol 600 (1.63 mg/g). In brief, different stresses enhanced proline contents in S. costus callus as follows: callus treated with $60 \mathrm{gL}^{-1} \mathrm{D}$-Manitol $(48.14 \mu \mathrm{M} / \mathrm{g})>60 \mathrm{gL}^{-1} \mathrm{D}$-Sorbitol $(18.45 \mu \mathrm{M} / \mathrm{g})>60 \mathrm{gL}^{-1}$ Sucrose $(17.79 \mu \mathrm{M} / \mathrm{g})>5 \mathrm{gL}^{-1}$ Poly ethylene glycol $600(1.63 \mu \mathrm{M} / \mathrm{g})$. Results presented here are in general agreement to earlier reports where, authors have reported proline accumulation in calli of sugarcane grown on different concentration of $\mathrm{PEG}^{49}$. Similarly, total proline level of 20\% PEG selected calli was reported to be 17 times higher than the non-selected calli of $O$. sativum ${ }^{50}$. Pradhan et al. $(2021)^{51}$ reported on the increasing trends in proline

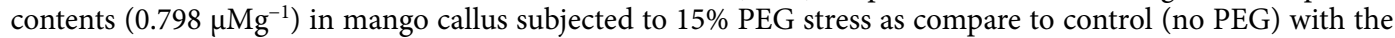
value of $0.080 \mu \mathrm{M} \mathrm{g}^{-1} \mathrm{FW}$. Similar increase in proline contents is also mentioned for $H$. annuus ${ }^{52}$ as well as rice in response to PEG stress ${ }^{53}$. Previously, D-sorbitol stress has resulted in more than four-fold increase in proline level in maize seedling ${ }^{54}$ and these results are in full agreement to those reported here.

Total flavonoids. Favonoids have protective functions for plants growing in soils that are rich in toxic metals. Here flavonoids contents showed significant variation among wild and in-vitro propagated plant as well as induced callus of $S$. costus. This variation in flavonoids content ranged from 0.90 to $59.89 \mathrm{mg} / \mathrm{g}$. Results showed that in-vitro propagated plants had the highest flavonoids contents $(59.892 \mathrm{mg} / \mathrm{g})$ followed by plants collected from wild (49.199 mg/g). Similarly, lowest flavonoids contents were reported in callus agitated on CPM-4 supplemented with $60 \mathrm{gL}^{-1}$ Sucrose (Fig. 4A). Comparing wild and in-vitro propagated plants, callus contained relatively scarce amount of flavonoids, and this is most likely due to plants were grown in laboratory environment with very much uniform environmental conditions. In natural habitats plants are well adapted and have evolved mechanisms to minimize injuries under extreme environmental conditions. The accumulation of flavonoids in the cells resulted by osmotic stress are often associated with a mechanisms that allow plants to tolerate harmful effects of water shortage. Further, accumulation of these solutes lower the osmotic potential of plant tissues at cellular level and hence allowing plants to sustain growth in stressful environments ${ }^{55}$. Ibrahim et al. $(2018)^{56}$ have also noted maximum level of total flavonoids in wild or natural P. barbatus as compared to in-vitro propagated plants and callus ${ }^{57}$.

Ascorbic acid contents. Maximum accumulation of Ascorbic acid $(373.801 \mathrm{mM} / \mathrm{g})$ was recorded in callus cultured on CPM-1 supplemented with $60 \mathrm{gL}^{-1} \mathrm{D}$-Sorbitol, followed by CPM-2 that had subjected to $\left(60 \mathrm{gL}^{-1}\right)$ D-Manitol stress $(373.801 \mathrm{mM} / \mathrm{g})$, while minimum amount was observed in callus grown on CPM (104.95 mM/g) (see Fig. 4b). Kamal et al. $(2020)^{58}$ have studied the optimization of suitable media for callus induction and ascorbic acids accumulation in Chinese cabbage cultivars. The authors have found maximum ascorbic acid accumulation in callus of root explant cultured on TDZ $\left(1.0 \mathrm{mgL}^{-1}\right)$, NAA $\left(0.25 \mathrm{mgL}^{-1}\right)$ and AgNO3 $\left(5.0 \mathrm{mgL}^{-1}\right)$, while minimum ascorbic acid was noted for callus grown from hypocotyl tissues cultured on TDZ $\left(1.0 \mathrm{mgL}^{-1}\right)$, NAA (1.0 $\left.\mathrm{mgL}^{-1}\right)$ and $\operatorname{AgNO} 3\left(9.0 \mathrm{mgL}^{-1}\right)$. Likewise, using the DPPH assay, free radical scavenging and antioxidant potential of in-vitro propagated $S$. corymbosa plants were compared with the wild plants in where the wild plants have shown highest free radical scavenging activity compared to the in-vitro propagated plants ${ }^{59}$. 

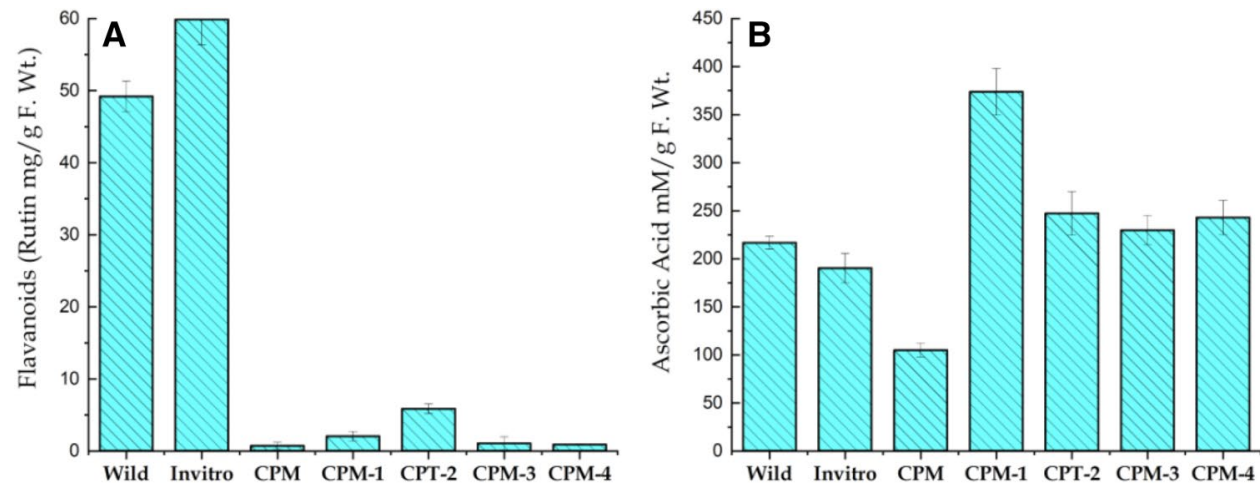

Figure 4. Variation in the Total Flavenoids (A) and Ascorbic acid (B) contents of S. costus collected from wild, micro propagated plant and induced callus grown on simple callus promoting media (CPM) supplemented with Kinetin $\left(0.5 \mathrm{mgL}^{-1}\right)$ and 2.4-D $\left(1.0 \mathrm{mgL}^{-1}\right)$ and callus subjected to various stresses i.e. $60 \mathrm{gL}^{-1} \mathrm{D}$-Sorbitol stress (CPM-1), $60 \mathrm{gL}^{-1}$ D-Manitol (CPM-2), $5 \mathrm{gL}^{-1}$ Poly ethylene glycol 600 (CPM-3) and $60 \mathrm{gL}^{-1}$ Sucrose (CPM-4).
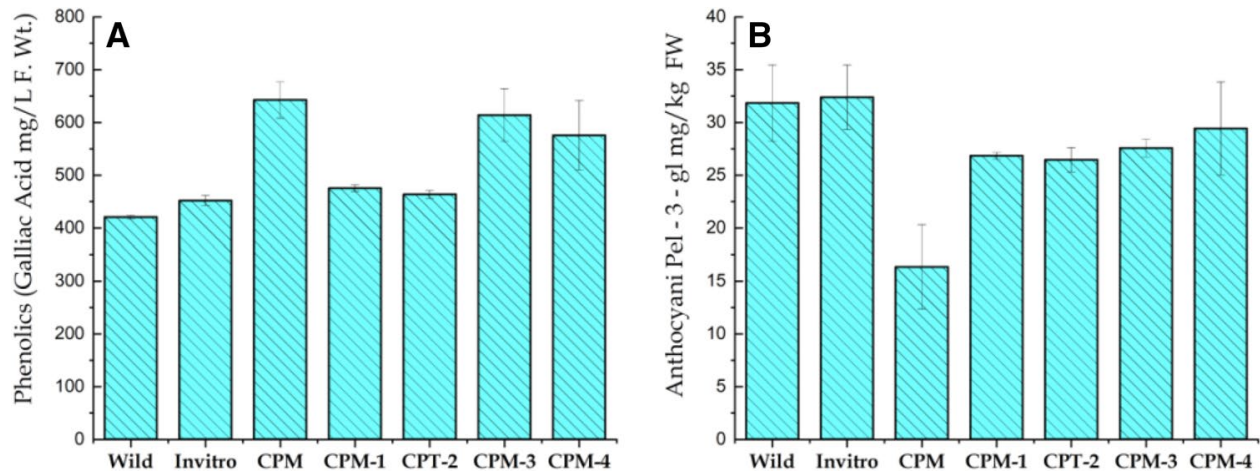

Figure 5. Variation in the Total Phenolics (A) and Anthocyanin (B) of S. costus collected from wild, micro propagated plant and induced callus. Different stresses for phytochemical comparison of callus grown on simple callus promoting media (CPM) supplemented with Kinetin $\left(0.5 \mathrm{mgL}^{-1}\right)$ and $2.4-\mathrm{D}\left(1.0 \mathrm{mgL}^{-1}\right)$ and callus subjected to various stresses i.e. $60 \mathrm{gL}^{-1} \mathrm{D}$-Sorbitol stress (CPM-1), $60 \mathrm{gL}^{-1} \mathrm{D}-\mathrm{Manitol}(\mathrm{CPM}-2), 5 \mathrm{gL}^{-1}$ Poly ethylene glycol 600 (CPM-3) and $60 \mathrm{gL}^{-1}$ Sucrose (CPM-4).

Total phenolic compounds. Phenolics compounds represent a diverse array of plant secondary metabolites, which are predominantly used as powerful scavengers of free radicals (Pietta, 2000) ${ }^{60}$. Here, highest phenolic contents $\left(642.72 \mathrm{mgL}^{-1}\right)$ accumulated in calli cultured on CPM when compared to wild or in-vitro propagated plantlet. Similarly, lowest levels of phenolic compounds $\left(420 \mathrm{mgL}^{-1}\right)$ were recorded in plants collected from wild (Fig. 5A). Increase in phenolic compounds accumulation (37\% and $34 \%$ ) was observed in callus treated with $100 \mathrm{mgL}^{-1}$ yeast extract and $50 \mathrm{mgL}^{-1}$ salicylic acid ${ }^{24}$. These finding are supported by those given in ElNabarawy et al. $(2015)^{61}$, where the culture medium supplemented with low concentration of yeast extract increased phenolic accumulation in micro propagated plants. Furthermore, Gorni and Pacheco (2016) ${ }^{62}$ have reported that $A$. millefolium treated with 0.5 and $1.0 \mathrm{mM}$ salicylic acid significantly increases phenolic contents. A slight increase in total phenolic content was found in callus treated with glycine $\left(200 \mathrm{mgL}^{-1}\right)$, yeast extracts $\left(500 \mathrm{mgL}^{-1}\right)$ and salicylic acid $\left(100 \mathrm{mgL}^{-1}\right)$. This increase of phenolic contents in callus cultures was related to mitochondrial activity; that is, while the cell dehydrogenase activity (FADH2/NADH) and the cytochrome C-oxidase decrease, the production of phenolic compounds increases ${ }^{63}$. On the other hand, variation in total phenolics within the mother source plant, micropropagated plants and callus subjected to different stresses may be attributed to changes in the levels of various phytohormones or other endogenous physiological pathways that occur in plant ${ }^{64}$. Also synthetic plant growth regulators used during the micro propagation pathways make a significant contribution in the production of secondary metabolites within the in-vitro cultured cells and tissues by controlling the expression of genes involved in the synthesis of secondary metabolites such as shikimate and flavonoids ${ }^{65}$.

Total anthocyanin. Anthocyanin contents were detected in the form of Pelargonidin-3-glucoside per kilogram of fresh sample. In the current analyses, in-vitro propagated plant possessed highest amounts of anthocyanin $(32.39 \mathrm{mg} / \mathrm{kg})$ followed by wild $(31.84 \mathrm{mg} / \mathrm{kg})$ whereas, lowest amount of anthocyanin was recorded in callus 


\begin{tabular}{|c|c|c|c|c|c|c|c|c|}
\hline \multirow[b]{2}{*}{ RT } & \multirow[b]{2}{*}{ Compound name } & \multirow[b]{2}{*}{ Molecular mass } & \multirow[b]{2}{*}{ Cas number } & \multirow{2}{*}{\begin{tabular}{|l|} 
CPM \\
\% area \\
\end{tabular}} & \multirow{2}{*}{\begin{tabular}{|l|} 
CPM-1 \\
\% area \\
\end{tabular}} & \multirow{2}{*}{$\begin{array}{l}\text { CPM-2 } \\
\% \text { area }\end{array}$} & \multirow{2}{*}{\begin{tabular}{|l|} 
CPM-3 \\
\% area \\
\end{tabular}} & \multirow{2}{*}{\begin{tabular}{|l|} 
CPM-4 \\
\% area \\
\end{tabular}} \\
\hline & & & & & & & & \\
\hline 10.13 & \begin{tabular}{|l|}
$\begin{array}{l}\text { Dodecane,2,6,10- } \\
\text { trimethyl }\end{array}$ \\
\end{tabular} & 212 & 3891-98-3 & 1.35 & 3.045 & & 1.97 & \\
\hline 13.04 & Hexadecane & 226 & 544-76-3 & 2.48 & 5.92 & & 4.57 & 3.73 \\
\hline 14.23 & $\begin{array}{l}\text { Bezene,1,4-bis(1,1- } \\
\text { dimethylethyl) }\end{array}$ & 190 & $1012-72-2$ & & & 8.67 & 5.31 & 5.17 \\
\hline 14.41 & \begin{tabular}{|l|} 
Benzene, \\
1,3bis(dimethylethyl)
\end{tabular} & 190 & $1014-60-4$ & 2.26 & & & & \\
\hline 14.92 & $\begin{array}{l}\text { Nonadecane,2,6,10,14 } \\
\text { tetramethyl }\end{array}$ & 324 & $55,124-80-6$ & & & & 7.55 & 4.31 \\
\hline 14.98 & Octacosane,1-Iodo & 520 & $900,406-32-2$ & & & 12.34 & & \\
\hline 15.24 & $\begin{array}{l}\text { Octadecane-2,6,10,14- } \\
\text { tetramethyl }\end{array}$ & 310 & $54,964-82-8$ & 4.08 & 6.85 & 12.34 & 3.20 & 9.40 \\
\hline 16.64 & Hentriacontane & 436 & 630-04-6 & 3.66 & 7.68 & 7.47 & 1.89 & 3.87 \\
\hline 18.4 & $\begin{array}{l}\text { Heptadecane,2,6,10,15- } \\
\text { Tetramethyl }\end{array}$ & 296 & $54,833-54-6$ & & 7.90 & & & 5.38 \\
\hline 18.31 & Tritetracontane & 604 & 7098-21-7 & & & & 5.46 & \\
\hline 18.32 & Dodecane,1-fluoro & 188 & 334-68-9 & & & 9.89 & & \\
\hline 19.13 & $\begin{array}{l}\text { Carbonic acid,decyl } \\
\text { undecyl ester }\end{array}$ & 356 & $900,383-16-0$ & 3.11 & & & & \\
\hline 20.7 & $\begin{array}{l}\text { 6-tetradecanesulfonicacid, } \\
\text { butyl ester }\end{array}$ & 334 & $20,028,280-27-4$ & & 10.30 & & & 10.62 \\
\hline 21.6 & $\begin{array}{l}\text { Nonadecane,2,6,10,14,18- } \\
\text { pentamethyl }\end{array}$ & 338 & $55,191-61-2$ & & 13.39 & 12.76 & 10.47 & 18.60 \\
\hline 21.7 & $\begin{array}{l}\text { Nonadecane,2,6,10,14 } \\
\text {-tetramethyl }\end{array}$ & 324 & $55,124-80-6$ & & & 22.43 & 16.90 & 14.28 \\
\hline 21.9 & $\begin{array}{l}\text { Eicosane,2,6,10,14,18- } \\
\text { pentamethyl }\end{array}$ & 352 & $51,794-16-2$ & & 13.39 & & 16.01 & \\
\hline 23.67 & Heneisane & 296 & 629-94-7 & & 4.28 & 7.04 & & 12.89 \\
\hline 24.65 & \begin{tabular}{|l|} 
Propanic acid,2- \\
methyl-,3,7-dimethyl- \\
2,6-octadienyl ester
\end{tabular} & 224 & $2345-24-6$ & 64.24 & & & & \\
\hline 25.24 & Alpha-maaliene & 204 & 489-28-1 & & 9.31 & & & \\
\hline 25.59 & Dotriacontane & 450 & 544,854 & & & & 12.29 & \\
\hline 26.4 & Tetrapentacotane & 758 & $5856-66-6$ & & 7.795 & & 14.37 & 5.92 \\
\hline 27.52 & Dotricotane & 450 & 544,854 & & & & & 5.84 \\
\hline 27.73 & Triacotane & 422 & $638-68-6$ & & 10.11 & 7.04 & & \\
\hline 28.7 & Selina-3,7(11)-diene & 204 & 6813-21-4 & 18.81 & & & & \\
\hline Total identification & 100 & 99.99 & 100 & 100 & 100 & & & \\
\hline
\end{tabular}

Table 6. Phytocomponents identified in ethyl acetate extract of $S$. costus callus grown on simple callus promoting media (Kinetin: $0.5 \mathrm{mgL}^{-1}$ and 2.4-D: $1.0 \mathrm{mgL}^{-1}$ ) and callus subjected to various stresses i.e. $60 \mathrm{gL}^{-1}$ D-Sorbitol stress (CPM-1), 60gL-1 D-Manitol (CPM-2), 5gL-1 Poly ethylene glycol 600 (CPM-3) and 60gL Sucrose (CPM-4).

grown on CPM (with no stress see Fig. 5B). A similar trend in callus cultures of A. cordata anthocyanin accumulations was achieved with a combination of either NAA or 2,4-D and Kinetin in comparison with auxins or cytokinins ${ }^{66}$. Similarly, maximum total anthocyanin contents $(3.3$ to $7.4 \mathrm{CV} / \mathrm{g}$ ) was reported from cultures on moderate level $\left(40\right.$ and $50 \mathrm{mM}$ ) of total nitrogen ${ }^{67}$. Our results are in agreements with several authors where, highest values of all estimated anthocyanin were recorded in shootlets of $A$. leptopus obtained from MS supplemented with $2 \mathrm{iP}(0.4 \mathrm{mg} / \mathrm{l})$ and IBA $\left(0.1 \mathrm{mgL}^{-1}\right)^{68}$. Similarly, calli derived from style of Crocus sativus showed anthocyanin pigment of $3.75 \times 10^{-7} \mathrm{mg} \mathrm{g}^{-1}$ on media supplemented with NAA $\left(2 \mathrm{mgL}^{-1}\right)$ and TDZ $\left(1 \mathrm{mgL}^{-1}\right)$ compared to that of calli produced from corm $2.52 \times 10^{-7} \mathrm{mg} \mathrm{g}^{-1} \mathrm{DW}^{69}$.

GC-MS analysis of callus ethyl acetate extract. GC-MS chromatograms of ethyl acetate extract of callus and callus subjected to different stresses revealed the presence of 24 compounds. The active principles with their retention time, molecular weight and peak area (\%) of the identified compounds that could contribute the medicinal quality of the plant are summarized in Table 6. The major components in the CPM extract were Propanic acid, 2-methyl-,3,7-dimethyl-2,6-octadienyl ester and Selina-3,7(11)-diene. The analysis of GC-MS chromatogram showed peaks of various phytochemical constituents present in ethyl acetate CPM extracts (Fig. 6). In contrast, major components identified in CPM-1 were Nonadecane, 2,6,10,14,18-pentamethyl, Nonadecane,2,6,10,14-tetramethyl and 6-tetradecane sulfonic acid, butyl ester (see Table 6, Fig. 7). In CPM-2, major phytocomponents were Octacosane,1-Iodo, Octadecane-2,6,10,14-tetramethyl, Nonadecane, 2,6,10,14,18-pen- 


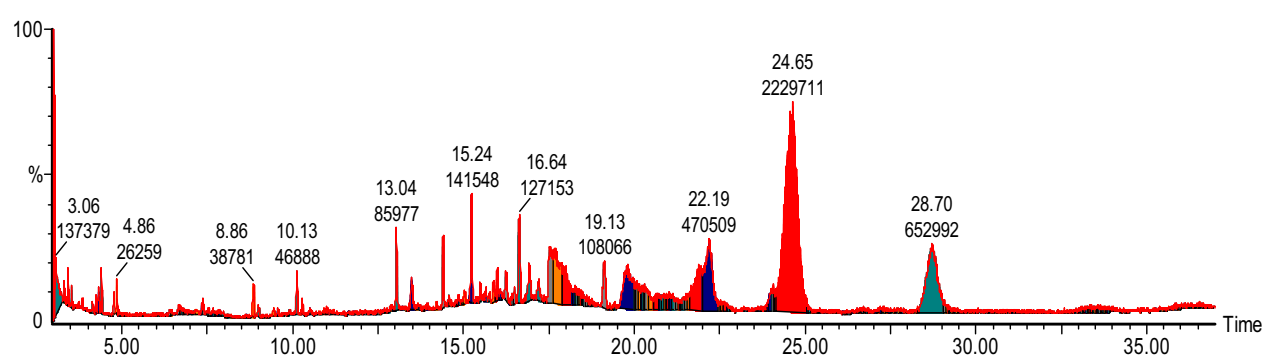

Figure 6. GC-MS Chromatogram of ethyl acetate extracts of callus grown on simple callus promoting media (CPM) supplemented with Kinetin $\left(0.5 \mathrm{mgL}^{-1}\right)$ and $2.4-\mathrm{D}\left(1.0 \mathrm{mgL}^{-1}\right)$.

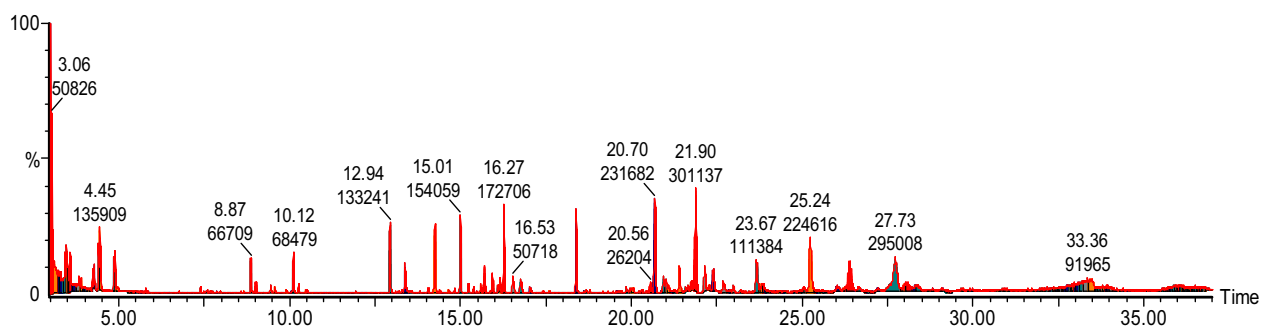

Figure 7. GC-MS Chromatogram of ethyl acetate extracts of callus subjected to $60 \mathrm{gL}^{-1} \mathrm{D}$-Sorbitol stress (CPM-1).

tamethyl and Nonadecane ,2,6,10,14-tetramethyl. Similarly, in CPM-3 and CPM-4 major phytocomponents recorded were Nonadecane,2,6,10,14-tetramethyl, Eicosane,2,6,10,14,18-pentamethyl, Tetrapentacotane and Nonadecane,2,6,10,14,18-pentamethyl, Nonadecane, 2,6,10,14-tetramethyl and Heneisane respectively (see supplementary Figs. 8-10 and Table 6). While, the phytocomponents such as Octadecane-2,6,10,14-tetramethyl and Hentriacontane were present in all the tasted samples. High amount of Octadecane-2,6,10,14-tetramethyl was observed in CPM-2, while the amount of Hentriacontane was higher in CPM-1. Previously, Gwari et al. $(2013)^{3}$ has reported 41 aromatic compounds from essential oil of $S$. costus roots extracts. Among the identified compounds Aldehyde like (7Z, 10Z, 13Z)-7, 10, 13-hexadecaterinal, ketones like dehydrocostus lactone, alcohols like elemol, g-costol, vulgarol B, valerenol, and terpinen-4-ol, etc. were found a major component. In addition, Esters and acids were found to be completely absent in root extracts of $S$. costus. Srinivasan et al. $(2016)^{70}$ studied the chemical compounds in costus oil and observed that n-hexadecanoic acid to be the major constituent in all examined essential oil accompanied with other fatty acids, hydrocarbons and mono-,di- sesquiterpenes. Recently, Deabes et al. (2021) ${ }^{71}$ identified 14 components from S. costus ethyl acetate extracts. Compounds like Butanedioic acid and 2TMS derivative were recorded in highest percentage followed by D-(-)-Fructofuranose, pentakis (trimethylsilyl) ether (isomer1), Androstan-17-one, 3-ethyl-3-hydroxy-, (5.alpha.)-, Caffeic acid, 3TMS derivative and L-(-)- Sorbofuranose and pentakis (trimethylsilyl) ether. This great variation in phytocomponents of $S$. costus may be attributed to factors related to ecotype, chemotype, phenophases and the variations in environmental conditions such as temperature, relative humidity, irradiance and photoperiod. Moreover, the genetic background may also affect the chemistry of secondary metabolites of plants ${ }^{72}$. Furthermore, exposure to various type stresses may result in drastic epigenetic modifications thereby, changing the transcriptional activities and the overall transcriptomic profile ${ }^{73}$. Recently it has been shown that stable phenotypes can be generated through epigenetic modifications and thereby increasing the success and survival of plants in their natural habitats. Although, we have not studied any such epigenetic modifications here, but these are very likely targets and are important consideration to be included in future studies.

\section{Conclusion}

Efficient protocols for large scale callus induction of four explants (seeds, leaf, petiole and internodes) as well as micro propagation from auxiliary buds of $S$. costus were developed. Callus formation was greatly influenced by type of explant used and maximum callus tissue with minimum time taken was record for seed explants. The best response to direct organogenesis was observed on media fortified with BAP $\left(2.0 \mathrm{mgL}^{-1}\right)$, NAA $\left(1.0 \mathrm{mgL}^{-1}\right)$ and GA3 $\left(0.25 \mathrm{mgL}^{-1}\right)$. Micropropagated plantlets suffer high mortality due to their slow acclimatization to ex-vitro conditions. In spite of the prior limited success with Asteraceae members in inducing roots during tissue culture and acclimatization; here, the regenerated plantlets had $87 \%$ of survival rate. We argue this survival rate could be further improved through biotization of micro propagated plants with endophytic bacteria and fungi. Here, phytochemical characterization and variability in metabolites such as total sugars, proline, flavonoids, ascorbic acid, phenolics and anthocyanin is recorded from callus, wild as well as micro propagated plantlets. It is also demonstrated that $S$. costus callus is rich source of various bioactive compounds as indicated in the GC-MS 
profiles. The remarkable variation in the secondary metabolites may be partly explained by the preexisting genetic variation within the populations of $S$. costus, understanding the role of epigenetic regulation in response to environmental stimuli, particularly in response to stresses is of paramount significance to the stability and survival of the plants in their natural habitat. The current work on this critically endangered species provides a baseline for future work including application of the newly evolved biotechnological tools that may speed up and ensure sustainability of the plant species, thereby enhancing conservation and management of $S$. costus in natural ecosystems.

\section{Approval and compliance with regulation}

The study was formally authorized by the Directorate of Academics and Research Hazara University Mansehra, Pakistan. Experimental research and field studies on selected plant, including the collection of plant material comply with relevant institutional guidelines and legislation.

\section{Statement for submission of specimen to University herbarium}

Specimen was collected from Makra, mountain peak (alt 3,878 m), situated in District Mansehra, KP Pakistan. Date 10-07-2019, GPS (lat 34.57439 $\mathrm{N}$, long 073.49580 E), collected by Ajmal Khan, Azhar Hussain Shah, and Abdul Majid, 57 (HUP).

\section{Data availability}

All data are available in the manuscript.

Received: 24 May 2021; Accepted: 17 November 2021

Published online: 08 December 2021

\section{References}

1. Vines, G. Herbal harvests with a future: towards sustainable sources for medicinal plants. (Plantlife International, 2004).

2. Zahara, K. et al. A review of therapeutic potential of Saussurea lappa-An endangered plant from Himalaya. Asian Pac. J. Trop. Med. 7, S60-S69 (2014).

3. Gwari, G., Bhandari, U., Andola, H. C., Lohani, H. \& Chauhan, N. Volatile constituents of Saussurea costus roots cultivated in Uttarakhand Himalayas India. Pharmacognosy Res. 5, 179 (2013).

4. Bisht, A. S. \& Chauhan, R. S. Phenological Studies of High Value Endangered Medicinal Herbs: Picrorhiza kurroa and Saussurea costus in Sub-alpine Regions of Garhwal Hiamalya, Uttarakhand India.

5. Cho, J. Y. et al. Cytotoxic and pro-apoptotic activities of cynaropicrin, a sesquiterpene lactone, on the viability of leukocyte cancer cell lines. Eur. J. Pharmacol. 492, 85-94 (2004).

6. Peng, Z. et al. Costunolide and dehydrocostuslactone combination treatment inhibit breast cancer by inducing cell cycle arrest and apoptosis through c-Myc/p53 and AKT/14-3-3 pathway. Sci. Rep. 7, 1-16 (2017).

7. Davies, K. M. \& Deroles, S. C. Prospects for the use of plant cell cultures in food biotechnology. Curr. Opin. Biotechnol. 26, 133-140 (2014).

8. Yasmin, S. et al. Plant growth promotion and suppression of bacterial leaf blight in rice by inoculated bacteria. PloS one 11, e0160688 (2016).

9. Murashige, T. \& Skoog, F. A revised medium for rapid growth and bio assays with tobacco tissue cultures. Physiol. Plant. 15, 473-497 (1962).

10. Hossain, A., Mishty, A. \& Mian, A. Numerical analysis for design optimization of microcantilever beams for measuring rheological properties of viscous fluid. Finite Elem. Anal. Des. 68, 1-9 (2013).

11. Storey, R. \& Jones, R. W. Betaine and choline levels in plants and their relationship to NaCl stress. Plant Sci. Lett. 4, 161-168 (1975).

12. Dubois, M., Gilles, K. A., Hamilton, J. K., Rebers, P. T. \& Smith, F. Colorimetric method for determination of sugars and related substances. Anal. Chem. 28, 350-356 (1956).

13. Bates, L. S., Waldren, R. P. \& Teare, I. Rapid determination of free proline for water-stress studies. Plant Soil 39, 205-207 (1973).

14. Csepregi, K., Kocsis, M. \& Hideg, É. On the spectrophotometric determination of total phenolic and flavonoid contents. Acta Biol. Hung. 64, 500-509 (2013).

15. Re, R. et al. Antioxidant activity applying an improved ABTS radical cation decolorization assay. Free Radical Biol. Med. 26, 1231-1237 (1999).

16. Singleton, V. L. \& Rossi, J. A. Colorimetry of total phenolics with phosphomolybdic-phosphotungstic acid reagents. Am. J. Enol. Vitic. 16, 144-158 (1965).

17. Giusti, M. M. \& Wrolstad, R. E. Characterization and measurement of anthocyanins by UV-visible spectroscopy. Curr. Protocols Food Anal. Chem., F1. 2.1-F1. 2.13 (2001).

18. Deventhiran, M. et al. Comparative phytochemical analysis of wild and micropropagated Cleome viscosa L. J. Appl. Pharm. Sci. 7, 83-88 (2017).

19. Rosy, B. A. \& Rosakutty, P. GC-MS analysis of methanol wild plant and callus extracts from three Cissus species, family Vitaceae. J. Chem. Pharm. Res. 4, 3420-3426 (2012).

20. Hassan, M. M., Azam, F. S., Chowdhury, M. H. \& Rahmatullah, M. Callus induction of Abrus precatorius: screening of phytohormones. Am. Eur. J. Sustain. Agric., 512-519 (2009).

21. Sen, M. K., Nasrin, S., Rahman, S. \& Jamal, A. H. M. In vitro callus induction and plantlet regeneration of Achyranthes aspera L, a high value medicinal plant. Asian Pac. J. Trop. Biomed. 4, 40-46 (2014).

22. Ardelean, M. et al. Cytological aspects and anthocyanin accumulation observed in Sedum telephium ssp. maximum L. callus. Roman. Biotechnol. Lett. 22, 13025 (2017).

23. Khoo, I.-C. Liquid crystals. Vol. 64 (John Wiley \& Sons, 2007).

24. Ali, S. et al. In vitro effects of GA 3 on morphogenesis of CIP potato explants and acclimatization of plantlets in field. In Vitro Cell. Dev. Biol. Plant 54, 104-111 (2018).

25. Sabeti, M., Zarghami, R. \& Zadeh, M. Effects of explants and growth regulators on callogenesis and somatic embryogenesis of Agria potato cultivar. Int. J. Agrisci. 3, 213-221 (2013).

26. Iralu, V. \& Upadhaya, K. Dormancy, storability, and germination of seeds in Magnolia punduana (Magnoliaceae). Botany $\mathbf{9 4}$, 967-973 (2016).

27. Wojtania, A., Skrzypek, E. \& Gabryszewska, E. Morphological and biochemical responses to gibberellic acid in Magnoliax'Spectrum’in vitro. Acta Biologica Cracoviensia. Series Botanica 58 (2016). 
28. Das, S. et al. Core-shell structured catalysts for thermocatalytic, photocatalytic, and electrocatalytic conversion of CO 2. Chem. Soc. Rev. 49, 2937-3004 (2020).

29. Martin, G. et al. An efficient micropropagation system for Celastrus paniculatus Willd.: a vulnerable medicinal plant. J. For. Res. 11, 461-465 (2006).

30. Rani, G., Talwar, D., Nagpal, A. \& Virk, G. Micropropagation of Coleus blumei from nodal segments and shoot tips. Biol. Plant. 50, 496-500 (2006).

31. Kaur, K., Verma, B. \& Kant, U. Plants obtained from the Khair tree (Acacia catechu Willd.) using mature nodal segments. Plant Cell Rep. 17, 427-429 (1998).

32. Sivaram, L. \& Mukundan, U. In vitro culture studies on Stevia rebaudiana. In vitro Cell. Dev. Biol. Plant 39, 520-523 (2003).

33. Rafiq, M., Dahot, M. U., Mangrio, S. M., Naqvi, H. A. \& Qarshi, I. A. In vitro clonal propagation and biochemical analysis of field established Stevia rebaudiana Bertoni. Pak. J. Bot 39, 2467-2474 (2007).

34. Dhar, U., Upreti, J. \& Bhatt, I. D. Micropropagation of Pittosporum napaulensis (DC.) Rehder \& Wilson-a rare, endemic Himalayan medicinal tree. Plant Cell, Tissue Organ Culture 63, 231-235 (2000).

35. Guo, Y.-X., Zhao, Y.-Y., Zhang, M. \& Zhang, L.-Y. Development of a novel in vitro rooting culture system for the micropropagation of highbush blueberry (Vaccinium corymbosum) seedlings. Plant Cell, Tissue and Organ Culture (PCTOC) 139, 615-620 (2019).

36. Cheepala, S., Sharma, N. \& Sahi, S. Rapid in vitro regeneration of Sesbania drummondii. Biol. Plant. 48, 13-18 (2004).

37. Kumar, S., Kumaria, S. \& Tandon, P. Efficient in vitro plant regeneration protocol from leaf explant of Jatropha curcas L-a promising biofuel plant. J. Plant Biochem. Biotechnol. 19, 273-275 (2010).

38. Wen, W. \& Yang, J. Study on the tissue culture and propagation system of Gentiana scabra Bunge. Med. Plant 1, 13-23 (2010).

39. Bekheet, S. Direct organogenesis of date palm (Phoenix dactylifera L.) for propagation of true-to-type plants. Sci. Agric. 4, 85-92 (2013).

40. Chandra, S., Bandopadhyay, R., Kumar, V. \& Chandra, R. Acclimatization of tissue cultured plantlets: from laboratory to land. Biotech. Lett. 32, 1199-1205 (2010).

41. Deb, C. \& Imchen, T. An efficient in vitro hardening technique of tissue culture raised plants. Biotechnology 9, 79-83 (2010).

42. del Rosario Espinoza-Mellado, M. et al. Biotization and in vitro plant cell cultures: plant endophyte strategy in response to heavy metals knowledge in assisted phytoremediation. Microbe Med. Remed. Environ. Contamin., 27-36 (2021).

43. Prado, R., Huerta, G. \& West, M. Bayesian time-varying autoregressions: Theory, methods and applications. Resenhas do Instituto de Matemática e Estatística da Universidade de São Paulo 4, 405-422 (2000).

44. Wang, Z. \& Stutte, G. W. The role of carbohydrates in active osmotic adjustment in apple under water stress. J. Am. Soc. Hortic. Sci. 117, 816-823 (1992)

45. Zhang, F., Yang, Y., He, W., Zhao, X. \& Zhang, L. Effects of salinity on growth and compatible solutes of callus induced from Populus euphratica. In Vitro Cell. Dev. Biol. Plant 40, 491-494 (2004).

46. Martin, K. Rapid in vitro multiplication and ex vitro rooting of Rotula aquatica Lour., a rare rhoeophytic woody medicinal plant. Plant Cell Rep. 21, 415-420 (2003).

47. Malik, A. A., Williams, C. A., Weston, K. L. \& Barker, A. R. Perceptual and prefrontal cortex haemodynamic responses to highintensity interval exercise with decreasing and increasing work-intensity in adolescents. Int. J. Psychophysiol. 133, 140-148 (2018).

48. Mehta, R., Sharma, S. \& Nath, A. K. In vitro selection and biochemical characterization of carnation (Diathus caryophyllus L.) callus culture tolerant to Alternaria dianthi. Indian J. Plant Physiol. 12, 120 (2007).

49. Felix, K. et al. Hydrogen-induced tolerance against osmotic stress in alfalfa seedlings involves ABA signaling. Plant Soil 445, 409-423 (2019).

50. Shah, A. H., Shah, S. H., Ahmad, H. \& Swati, Z. A. Adaptation to polyethylene stress maintains totipotency of cell lines of Oryza sativa L. CV Swat-1 for a longer period. Pak. J. Bot 44, 313-316 (2012).

51. Pradhan, S. et al. Poly ethylene glycol mediated in vitro screening and physico-biochemical changes induced in mango callus due to moisture stress. Plant Cell, Tissue Organ Culture PCTOC 145, 155-172 (2021).

52. Hassan, A. \& Roy, S. Micropropagation of Smilax zeylanica L., a perennial climbing medicinal shrub, through axillary shoot proliferation. Bangladesh J. Life Sci 16, 33-39 (2004).

53. Ahmad, M. S. A., Javed, F. \& Ashraf, M. Iso-osmotic effect of $\mathrm{NaCl}$ and $\mathrm{PEG}$ on growth, cations and free proline accumulation in callus tissue of two indica rice (Oryza sativa L.) genotypes. Plant Growth Reg. 53, 53-63 (2007).

54. Jain, M., Tiwary, S. \& Gadre, R. Sorbitol-induced changes in various growth and biochemici parameters in maize. Plant Soil Environ. 56, 263-267 (2010).

55. Razavizadeh, R. \& Adabavazeh, F. Effects of sorbitol on essential oil of Carum copticum L. under in vitro culture. Rom. Biotechnol. Lett. 22, 12281-12289 (2017).

56. Ibrahim, S. R. et al. Lipoxygenase inhibitors flavonoids from Cyperus rotundus aerial parts. Rev. Bras 28, 320-324 (2018).

57. Khan, T. et al. Melatonin-enhanced biosynthesis of antimicrobial AgNPs by improving the phytochemical reducing potential of a callus culture of Ocimum basilicum L var thyrsiflora. RSC Adv. 7, 38699-38713 (2017).

58. Kamal, O. M., Shah, S. H. A., Li, Y., Hou, X. \& Li, Y. Production of ascorbic acid, total protein, callus and root in vitro of nonheading Chinese cabbage by tissue culture. Mol. Biol. Rep. 47, 6887-6897 (2020).

59. Narayan, M., Thimmaraju, R. \& Bhagyalakshmi, N. Interplay of growth regulators during solid-state and liquid-state batch cultivation of anthocyanin producing cell line of Daucus carota. Process Biochem. 40, 351-358 (2005).

60. Pietta, P.-G. Flavonoids as antioxidants. J. Nat. Prod. 63, 1035-1042 (2000).

61. El-Nabarawy, M., El-Kafafi, S., Hamza, M. \& Omar, M. The effect of some factors on stimulating the growth and production of active substances in Zingiber officinale callus cultures. Ann. Agric. Sci. 60, 1-9 (2015).

62. Gorni, P. H. \& Pacheco, A. C. Growth promotion and elicitor activity of salicylic acid in Achillea millefolium L. Afr. J. Biotech. 15, 657-665 (2016).

63. Dias, M. I., Sousa, M. J., Alves, R. C. \& Ferreira, I. C. Exploring plant tissue culture to improve the production of phenolic compounds: a review. Ind. Crops Prod. 82, 9-22 (2016).

64. Surveswaran, S., Cai, Y.-Z., Xing, J., Corke, H. \& Sun, M. Antioxidant properties and principal phenolic phytochemicals of Indian medicinal plants from Asclepiadoideae and Periplocoideae. Nat. Prod. Res. 24, 206-221 (2010).

65. Sakakibara, H., Takei, K. \& Hirose, N. Interactions between nitrogen and cytokinin in the regulation of metabolism and development. Trends Plant Sci. 11, 440-448 (2006).

66. Murthy, H. N., Lee, E.-J. \& Paek, K.-Y. Production of secondary metabolites from cell and organ cultures: strategies and approaches for biomass improvement and metabolite accumulation. Plant Cell, Tissue Org. Culture PCTOC 118, 1-16 (2014).

67. Irshad, M. et al. Accumulation of anthocyanin in callus cultures of red-pod okra [Abelmoschus esculentus (L.) Hongjiao] in response to light and nitrogen levels. Plant Cell, Tissue Organ Cul PCTOC 134, 29-39 (2018).

68. Youssef, N. M., Taha, L. S., El-Khalek, A. \& Nagy, S. Secondary metabolites characterization of in vitro propagated Antigonon leptopus cultures. Egypt. J. Chem. 64, 923-932 (2021).

69. Moradi, A., Zarinkamar, F., Caretto, S. \& Azadi, P. Influence of thidiazuron on callus induction and crocin production in corm and style explants of Crocus sativus L. Acta Physiol. Plant. 40, 1-8 (2018).

70. Srinivasan, J., Liu, C. \& Kelly, R. Geometric evolution of flux from a corroding one-dimensional pit and its implications on the evaluation of kinetic parameters for pit stability. J. Electrochem. Soc. 163, C694 (2016). 
71. Deabes, M., Aboulthana, W., Marzouk, E.E.-D., Mohamed, M. I. \& Ahmed, K. A. Evaluation of hepato-and neuroprotective effect of chemical constituents in Saussurea costus extract against the toxicity induced by chloropyrofos ethyl in rats. Egypt. J. Chem. 64, 631-647 (2021).

72. Negi, J. S. et al. Antidiarrheal activity of methanol extract and major essential oil contents of Saussurea lappa Clarke. Afr. J. Pharm. Pharmacol 7, 474-477 (2013).

73. Thiebaut, F., Hemerly, A. S. \& Ferreira, P. C. G. A role for epigenetic regulation in the adaptation and stress responses of non-model plants. Front. Plant Sci. 10, 246 (2019).

\section{Author contributions}

A.K. collected the data carried out lab work and drafted the manuscript. A.H.S. and N.A. conceived the overall project, reviewed, edited and finalized the manuscript.

\section{Funding}

The authors deeply acknowledge Higher Education Commission (HEC), Islamabad, Pakistan for providing financial assistance to this project (NRPU Project No. 20-4253).

\section{Competing interests}

The authors declare to have no conflict of interest.

\section{Additional information}

Supplementary Information The online version contains supplementary material available at https://doi.org/ 10.1038/s41598-021-03032-1.

Correspondence and requests for materials should be addressed to A.H.S.

Reprints and permissions information is available at www.nature.com/reprints.

Publisher's note Springer Nature remains neutral with regard to jurisdictional claims in published maps and institutional affiliations.

(c) (i) Open Access This article is licensed under a Creative Commons Attribution 4.0 International License, which permits use, sharing, adaptation, distribution and reproduction in any medium or format, as long as you give appropriate credit to the original author(s) and the source, provide a link to the Creative Commons licence, and indicate if changes were made. The images or other third party material in this article are included in the article's Creative Commons licence, unless indicated otherwise in a credit line to the material. If material is not included in the article's Creative Commons licence and your intended use is not permitted by statutory regulation or exceeds the permitted use, you will need to obtain permission directly from the copyright holder. To view a copy of this licence, visit http://creativecommons.org/licenses/by/4.0/.

(C) The Author(s) 2021 